\title{
The effect of pelleting on the voluntary intake and digestibility of leaf and stem fractions of three grasses
}

\author{
BY M. A. LAREDO* aNd D. J. MINSON \\ Division of Tropical Agronomy, CSIRO, Cunningham Laboratory, \\ St Lucia, Queensland, Australia
}

(Received I I March I974-Accepted 29 April 1974)

\begin{abstract}
I. Leaf is eaten in greater quantities than stem of similar digestibility. To determine whether this difference is caused by physical or chemical factors, leaf and stem fractions from Digitaria decumbens, Chloris gayana and Setaria splendida were fed ad lib. to sheep in the chopped and pelleted forms. Pellets were made from leaf and stem which had been ground through a screen with $3 \mathrm{~mm}$ holes. All sheep received a protein and mineral supplement.

2. Voluntary intake of chopped leaf was $34 \%$ higher than that of the chopped stem fraction $\left(40.3\right.$ and $30.0 \mathrm{~g} / \mathrm{kg}$ body-weight ${ }^{0.75}$ respectively, $\left.P<0.01\right)$ although dry matter digestibility ratios were similar $(0.478$ and 0.450 respectively, $P>0.05)$. The higher intake of leaf was associated with a larger surface area (13400 and $5200 \mathrm{~mm}^{2} / \mathrm{g}$ for chopped leaf and stem respectively), lower bulk density (60 and $180 \mathrm{~kg} / \mathrm{m}^{3}$ respectively) and lower neutral-detergent fibre (706 and $724 \mathrm{~g} / \mathrm{kg}$ respectively), acid-detergent fibre $\left(3_{3} 3\right.$ and $4 \mathrm{I} 3 \mathrm{~g} / \mathrm{kg}$ respectively) and lignin ( 42 and $59 \mathrm{~g} / \mathrm{kg}$ respectively) contents. Chopped leaf was retained in the reticulo-rumen for a shorter time than the stem fraction (19.9 and $26.4 \mathrm{~h}$ respectively).

3. Grinding and pelleting increased the voluntary intake of the leaf fraction by $88 \%$ and the stem fraction by $60 \%$. This increased voluntary intake caused by grinding and pelleting was not accompanied by any significant changes in the chemical composition of the diet. Grinding and pelleting reduced the time that the food was retained in the reticulo-rumen and this change appeared sufficient to account for the observed increases in voluntary intake.

4. It was concluded that the higher intake of the leaf fraction of grasses is caused by differences in retention time of food in the reticulo-rumen. These differences in retention time are caused by differences in physical properties and not chemical composition.
\end{abstract}

Studies with separated leaf and stem of five tropical grasses have shown the voluntary intake of leaf to be $46 \%$ higher than that of stem despite a slightly lower dry matter (DM) digestibility of the leaf fraction (Laredo \& Minson, 1973). This higher intake of the leaf was associated with a larger surface area initially available to bacterial degradation and a shorter retention time of DM in the reticulo-rumen. When the leaf and stem were finely ground there was no difference in the rate of DM digestion in vitro (Laredo \& Minson, I973). The leaf fractions contained more nitrogen but less fibre and lignin than the corresponding stem fractions.

If the voluntary intake of leaf and stem fractions is limited by physical factors, then voluntary intake will be increased if the physical properties of the diet are changed by grinding and pelleting. However, if the low intake of the stem is caused by a nutrient deficiency then grinding and pelleting will not increase voluntary intake (Minson, I967).

The object of this study was to identify the cause of the lower voluntary intake of stem. Measurements were made of the digestibility of leaf and stem fractions of three tropical grasses when fed chopped or pelleted and their voluntary intake by sheep.

\footnotetext{
* Present address: University of Tolima, Colombia.
} 


\section{EXPERIMENTAL}

\section{Diets}

Pure swards of Digitaria decumbens Stent (pangola grass), Chloris gayana (Rhodes grass, Commonwealth Plant Introduction (CPI) number I6710) and Setaria splendida (CPI I 5899 ) were planted in November I 968 in $325^{\circ} \mathrm{m}^{2}$ plots at Lawes in south-east Queensland $\left(27^{\circ} 30^{\prime} \mathrm{S}, 152^{\circ} 20^{\prime} \mathrm{E}\right.$, altitude $\left.120 \mathrm{~m}\right)$. In the following years the swards were regularly fertilized and cut. In December 1972 the swards were mown and the grass discarded. Urea and superphosphate were applied at the rate of $75^{\circ}$ and $500 \mathrm{~kg} / \mathrm{ha}$ respectively and the plots irrigated with water equivalent to a rainfall of $50 \mathrm{~mm}$ to encourage rapid initial regrowth. The $D$. decumbens, $C$. gayana and $S$. splendida were cut with a tractor-mounted reciprocating mower after regrowing for 56,127 and $150 \mathrm{~d}$ respectively. The grass was wilted in the field before being dried in a batch drier with an inlet temperature of $100^{\circ}$. The dried grass was chopped into $20-40 \mathrm{~mm}$ lengths and stored in hessian sacks until separated into leaf and stem fractions.

Proportions of each of the three cuts $(2000 \mathrm{~kg})$ were partly separated into a 'leaf' and 'stem' fraction using a specific-gravity separator (Harmond, Klein \& Branderberg 196I). The machine used was designed for cleaning seed but proved reasonably effective in separating the dense stem from the lighter leaf fraction. The chaffed grass was fed by hand onto the $\mathrm{I} .25 \times 0.5 \mathrm{~m}$ perforated oscillating deck of the machine. The slant of the deck and its oscillating motion moved the chaff over the deck while the air blowing through the deck caused the chaff to stratify into 'leaf' and 'stem' fraction. Fine leaf and dust representing approximately 10\% of the chaffed grass was blown off the sorting table. 'This dust was not added to the 'leaf' fraction, since it was essential to produce 'leaf' and 'stem' fractions with the minimum of difference in particle size if a valid comparison of food intake was to be achieved. Approximately half of each fraction was weighed into hessian sacks ready for feeding and samples were taken for DM determination, chemical and physical analysis and the measurement of the proportion of leaf and stem. The remaining half of each fraction was ground in a hammer-mill fitted with a $3 \mathrm{~mm}$ screen and made into pellets $13 \mathrm{~mm}$ in diameter and $20-30 \mathrm{~mm}$ long. Dried, ground samples of each of the diets were analysed for $\mathrm{N}$ by the Kjeldahl method (Association of Official Agricultural Chemists, r965), neutral-detergent fibre (NDF) (Van Soest, I963) and acid-detergent fibre (ADF) (Clancy \& Wilson, r966), lignin (Van Soest, r963; modification B, McLeod \& Minson, I97I), ash at $560^{\circ}$ and phosphorus by emission spectroscopy (Johnson \& Simons, I 972).

The surface area/g food could only be determined approximately. The projected area of the samples was determined with an automatic leaf area meter and the surface area/g calculated by multiplying the projected area by 2 and by dividing by the dry weight of the sample.

The bulk density of each fraction was determined for both chopped and pelleted samples. A sample of diet ( $100 \mathrm{~g}$ ) was placed in a measuring cylinder ( $90 \mathrm{~mm}$ diameter) and gently tapped until there was no further reduction in volume. Density was calculated as $\mathrm{kg} / \mathrm{m}^{3}$. 
Particle size of the twelve diets was determined using sieves according to the method recommended by the American Society of Agricultural Engineers (1967) as modified by Tetlow \& Wilkins (1972). Results of these sieve tests were expressed as a modulus of fineness (American Society of Agricultural Engineers, 1967). The approximate surface area of the ground diet was calculated from the 'sieve test' results assuming that all food particles were spheres.

\section{Animals and housing}

Forty-eight Merino wether sheep weighing between 30 and $42 \mathrm{~kg}$ were used to measure voluntary intake and digestibility in two $17 \mathrm{~d}$ trials each with a $7 \mathrm{~d}$ preliminary period followed by a ro $\mathrm{d}$ measurement period with four sheep receiving each of the grass diets. For the second trial the same sheep were re-randomized before allocating the twelve grass diets. The sheep were drenched at the beginning of each trial with thiobendazole to reduce any effects of internal parasites. The stem fraction of two cuts of the grass contained less than $10 \mathrm{~g} \mathrm{~N} / \mathrm{kg}$, and with these diets voluntary intake was likely to be depressed by a $\mathrm{N}$ deficiency (Milford \& Minson, 1966). To eliminate the possibility of a protein deficiency, all sheep were drenched with $20 \mathrm{~g}$ casein/d. To eliminate any difference in mineral composition that might limit voluntary intake all sheep were offered a mineral mixture ad lib. The mineral mixture had the following composition $(\mathrm{g} / \mathrm{kg})$ : $\mathrm{P}_{130}$, calcium 230 , sulphur 70 and sodium 80 . Each sheep was fitted with a canvas harness and faeces collection bag (Weston, 1959) and kept indoors in a galvanized-iron metabolism cage (Minson \& Milford, 1969).

The sheep were weighed on a platform scale at the beginning and end of the two ro $\mathrm{d}$ measurement periods. Metabolic size was calculated as the mean body-weight $t^{0.75}$ $\left(\mathrm{W}^{0.75}, \mathrm{~kg}\right)$.

\section{Determination of voluntary food intake}

Ad lib. feeding was ensured by offering on the ist day of the preliminary period about $250 \mathrm{~g}$ food in excess of the expected voluntary intake and this level of excess food on offer was maintained throughout the study. Each of the grass diets was given to four sheep in the first trial and to a different four sheep in the second trial. Uneaten food was removed at the end of the $7 \mathrm{~d}$ preliminary period and the voluntary intake was determined during the next $10 \mathrm{~d}$ with $250 \mathrm{~g}$ excess food. All intake results are expressed as g/unit metabolic size.

\section{Digestibility}

The faeces were collected daily during the period of $10 \mathrm{~d}$ in which voluntary intake was measured, and dried at $100^{\circ}$. At the end of the $10 \mathrm{~d}$ the total quantity of faecal DM produced was weighed. The dried faeces were analysed for ash, NDF, ADF and lignin using the same methods as were applied to the twelve diets. 


\section{Food retention in the reticulo-rumen}

The retention time of the different diets in the reticulo-rumen was determined with a separate group of fistulated sheep using the technique described by Minson (I966). Four wethers, with $80 \mathrm{~mm}$ rumen fistulas, were kept in a room with constant temperature, light and sound and fed in turn known quantities of all twelve chopped or pelleted diets every hour for ro $d$ periods using an automatic feeder (Minson \& Cowper, r966). Uneaten food was automatically removed each hour to prevent the accumulation of food residues and failure of the sheep to eat at hourly intervals. The total contents of the reticulo-rumen were removed $30 \mathrm{~min}$ after feeding, weighed and sampled for determination of $\mathrm{DM}$ at $100^{\circ}$. The dried samples of digesta were ground and analysed for total ash. The apparent retention times of the organic matter were calculated by dividing the total organic matter in the reticulo-rumen by the mean quantity of organic matter eaten each hour (Minson, 1966).

\section{RESULTS}

\section{Composition of diet}

The leaf and stem fractions produced by gravity separation were not $100 \%$ pure leaf or pure stem. The leaf fraction contained leaf lamina, seed head and leaf sheath that had separated from the stem, and lighter fractions of stem while the stem fraction contained leaf sheath, true stem and some leaf lamina. The stem fraction contained less than $10 \%$ leaf lamina, but for the leaf fraction the purity was very much less, due to the presence of lighter stems and seed head (Table $r$ ).

The chopped leaf fractions of all three grasses had a slightly lower modulus of fineness than the corresponding stem fractions (Table r). Grinding and pelleting reduced the modulus of fineness but the ground leaf had a lower modulus of fineness than the ground stem.

Bulk density of the chopped stem fraction was three times greater than that of chopped leaf but when ground and pelleted there was little difference in bulk density between leaf and stem fractions (Table I). The leaf fraction contained more ash, $\mathrm{N}$ and $P$ than the stem fractions while the stem fraction contained more NDF, ADF and lignin than the leaf fraction (Table I).

\section{Voluntary intake}

With all three grasses, the voluntary intake of leaf was significantly higher $(P<$ O.OI) than that of stem obtained from the same material (Table 2). The mean intake of the leaf was $34 \%$ higher than that of the stem fraction. Pelleting increased the voluntary intake of leaf from a mean level of 40.3 to $75^{.9} \mathrm{~g} / \mathrm{kg} \mathrm{W}^{0.75}$, an increase of $35^{.6} \mathrm{~g} / \mathrm{kg} \mathrm{W} \mathrm{W}^{0.75}(P<0.0 \mathrm{I})$. Pelleting the stem fraction increased voluntary intake from $30^{\circ} \circ$ to $48.0 \mathrm{~g} / \mathrm{kg} \mathrm{W}^{0.75}(P<0.0 \mathrm{r})$. Thus pelleting increased the voluntary intake of leaf and stem by 88 and $60 \%$ respectively. 


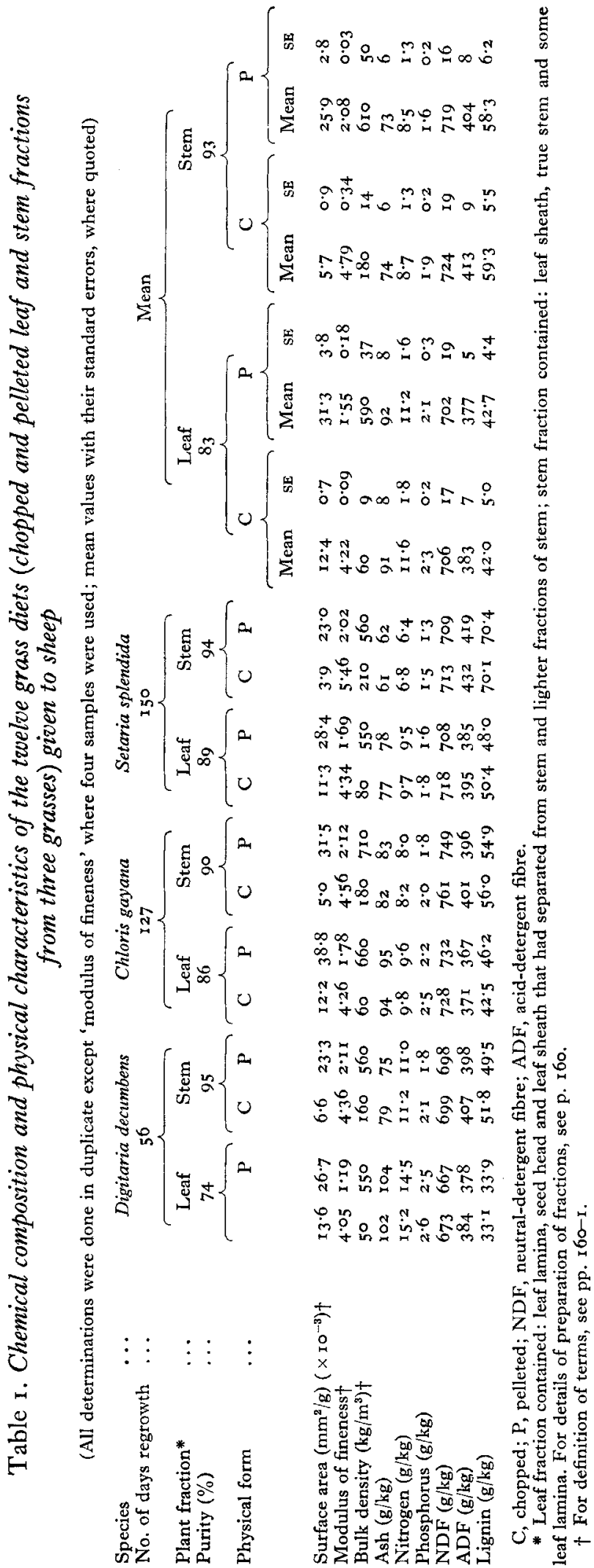




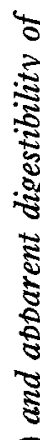

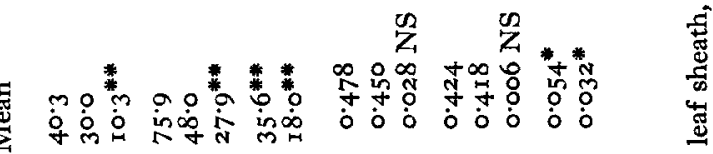

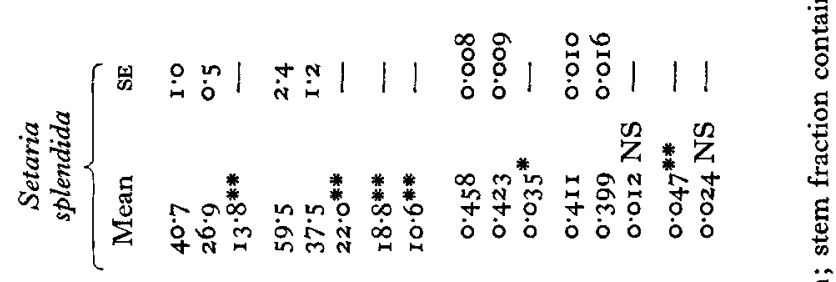

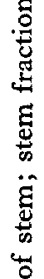

s.

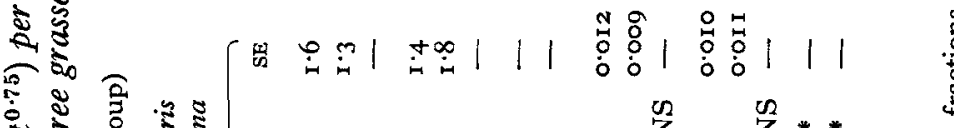

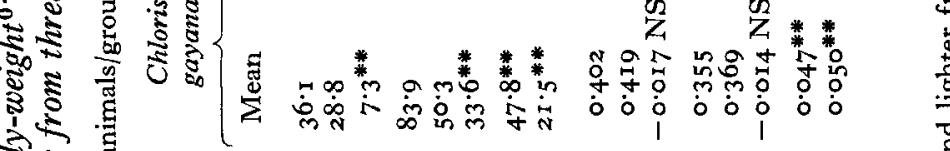

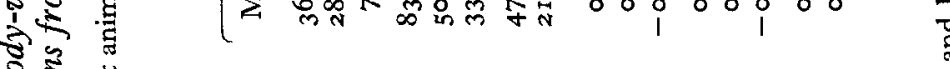

证

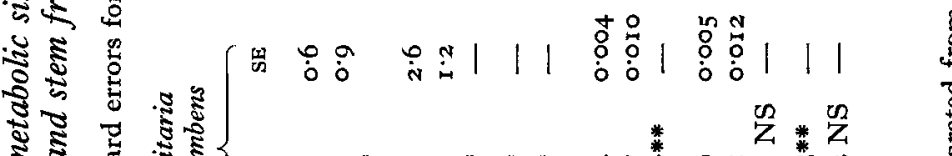

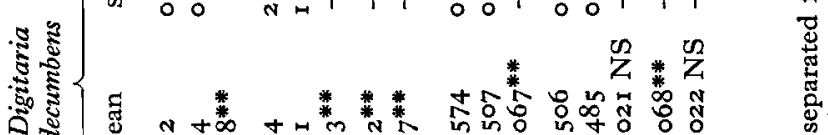

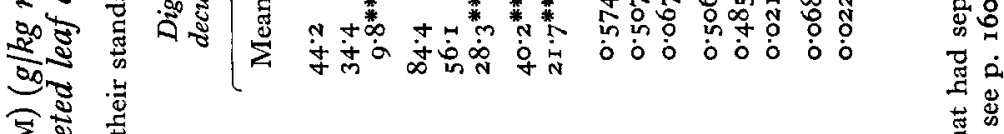

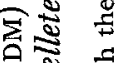

tक

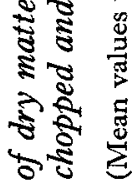

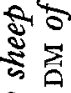

3

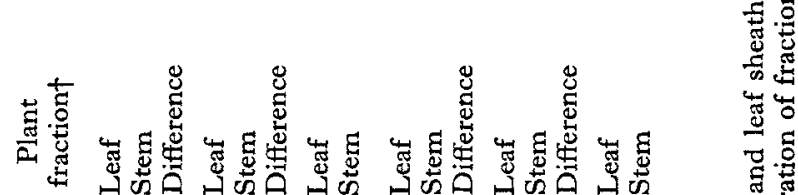

है

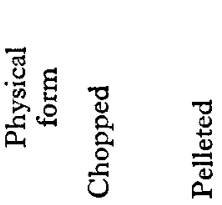
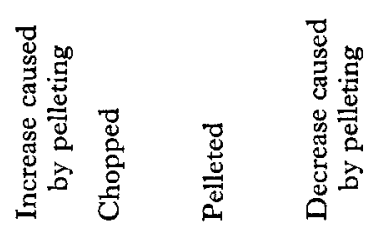


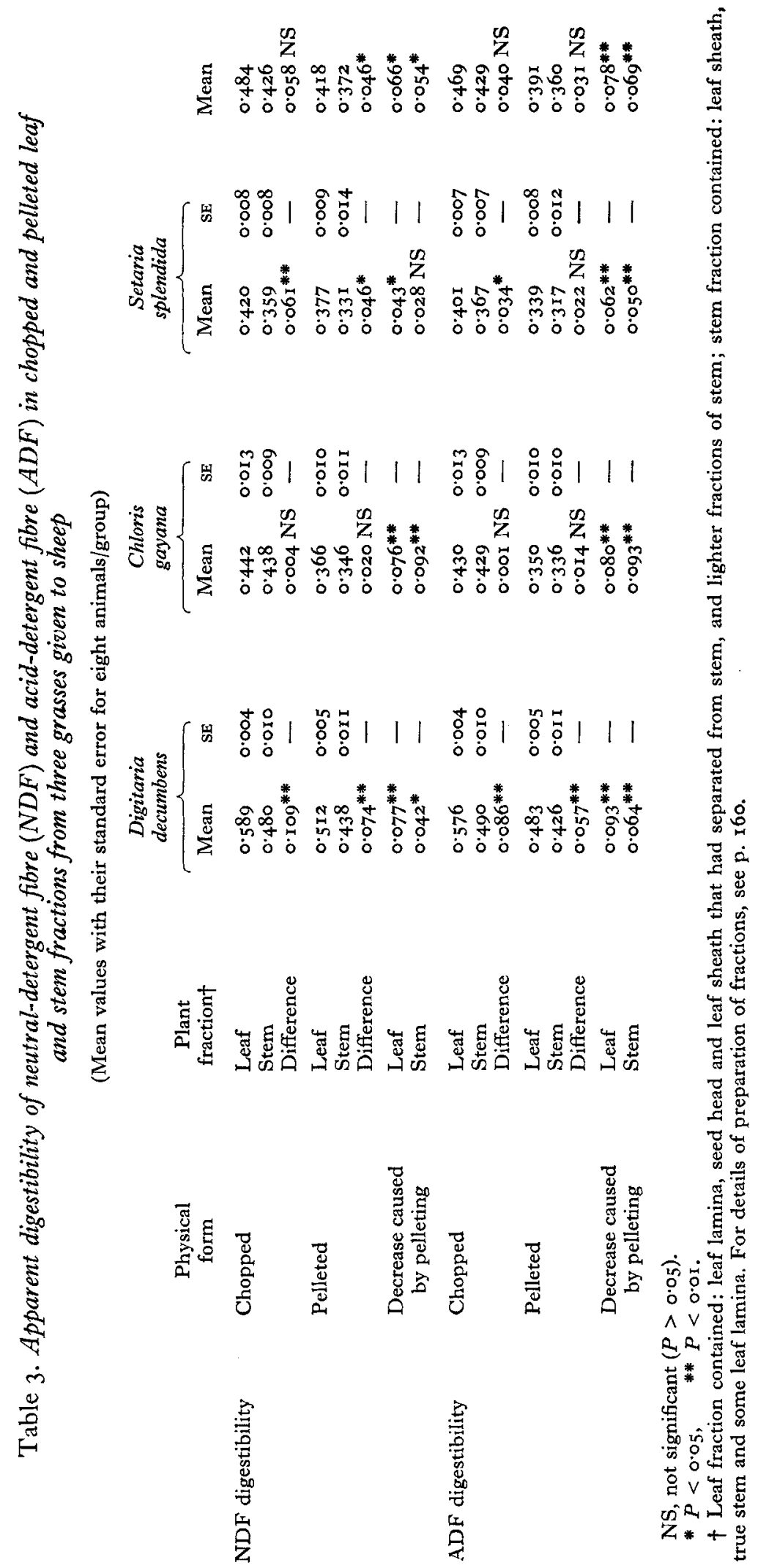


Table 4. Mean retention time (h) of dietary organic matter in the reticulo-rumen of sheep given chopped and pelleted leaf and stem fractions from three grasses

(Mean values with their standard errors for four animals/group)

\begin{tabular}{|c|c|c|c|c|c|c|c|c|}
\hline \multirow{2}{*}{$\begin{array}{l}\text { Physical } \\
\text { form }\end{array}$} & \multirow{2}{*}{$\begin{array}{c}\text { Plant } \\
\text { fractiont }\end{array}$} & \multicolumn{2}{|c|}{$\begin{array}{l}\text { Digitaria } \\
\text { decumbens }\end{array}$} & \multicolumn{2}{|c|}{$\begin{array}{l}\text { Chloris } \\
\text { gayana }\end{array}$} & \multicolumn{2}{|c|}{$\begin{array}{c}\text { Setaria } \\
\text { splendida }\end{array}$} & \multirow[b]{2}{*}{ Mean } \\
\hline & & $\overline{\text { Mean }}$ & $\overrightarrow{\mathrm{SE}}$ & Mean & $\overrightarrow{S E}$ & Mean & $\mathrm{SE}$ & \\
\hline Chopped & $\begin{array}{l}\text { Leaf } \\
\text { Stem } \\
\text { Difference }\end{array}$ & $\begin{array}{l}17 \cdot 9 \\
25 \cdot 0 \\
7 \cdot 1 * *\end{array}$ & $\begin{array}{l}\text { I. } \\
\text { I. } \\
-\end{array}$ & $\begin{array}{c}20 \cdot 7 \\
26 \cdot 5 \\
5 \cdot 8 * *\end{array}$ & $\begin{array}{l}0.5 \\
0.5 \\
-\end{array}$ & $\begin{array}{c}21 \cdot 2 \\
27 \cdot 7 \\
6 \cdot 5^{* * *}\end{array}$ & $\begin{array}{l}0.9 \\
\mathrm{x} .5 \\
-\end{array}$ & $\begin{array}{l}19 \cdot 9 \\
26 \cdot 4 \\
6 \cdot 5 * *\end{array}$ \\
\hline Pelleted & $\begin{array}{l}\text { Leaf } \\
\text { Stem } \\
\text { Difference }\end{array}$ & $\begin{array}{c}13.4 \\
18 \cdot 8 \\
5.4^{*}\end{array}$ & $\begin{array}{l}\mathrm{I} \cdot 5 \\
0.9 \\
\end{array}$ & $\begin{array}{c}16 \cdot 4 \\
18 \cdot 4 \\
2 \cdot 0^{*}\end{array}$ & $\begin{array}{l}0.4 \\
0.3 \\
-\end{array}$ & $\begin{array}{l}16 \cdot 2 \\
22 \cdot 0 \\
5 \cdot 8^{* * *}\end{array}$ & $\begin{array}{l}0.8 \\
0.7 \\
-\end{array}$ & $\begin{array}{l}15 \cdot 3 \\
19 \cdot 7 \\
4^{\circ} 4^{* *}\end{array}$ \\
\hline Change caused by pelleting & $\begin{array}{l}\text { Leaf } \\
\text { Stem }\end{array}$ & $\begin{array}{l}4 \cdot 5^{* * *} \\
6 \cdot 2^{* *}\end{array}$ & - & $\begin{array}{l}4 \cdot 3^{* * *} \\
8 \cdot I^{* *}\end{array}$ & - & $\begin{array}{l}5 \cdot 0^{* *} \\
5 \cdot 7^{* *}\end{array}$ & - & $\begin{array}{l}4 \cdot 6 * * \\
6 \cdot 7^{* * *}\end{array}$ \\
\hline
\end{tabular}

* $P<0.05, \quad * * P<0.01$.

$\dagger$ Leaf fraction contained: leaf lamina, seed head and leaf sheath that had separated from stem, and lighter fractions of stem; stem fraction contained: leaf sheath, true stem and some leaf lamina. For details of preparation of fractions, see p. I6o.

\section{DM digestibility}

The DM digestibility of the leaf fraction in $D$. decumbens and $S$. splendida was higher than that of the stem fraction $(P<0.05)$ but for $C$. gayana the stem was slightly more digestible than the leaf (Table 2). When pelleted the mean DM digestibility of the leaf fraction was reduced by 0.054 while the mean digestibility of the stem fraction was reduced by 0.032 . Thus there was very little difference in mean digestibility between leaf and stem fractions when pelleted.

\section{Fibre digestibility}

The digestibility of the NDF and ADF was higher in the leaf fraction than in the stem fractions although the difference was not significant in the instance of $C$. gayana (Table 3). Pelleting reduced the digestibility of NDF and ADF in both leaf and stem fractions $(P<0.0 \mathrm{I})$.

\section{Retention time for food in the reticulo-rumen}

The stem fraction was retained for $26.4 \mathrm{~h}$ compared with a mean value of $19.9 \mathrm{~h}$ for the leaf fractions that were eaten in greater quantities (Table 4). Grinding and pelleting reduced the retention time of both the leaf and stem fraction but even after pelleting the stem was still retained significantly longer in the reticulo-rumen than the leaf fraction (Table 4).

Fig. I shows the relationship between voluntary intake and the reciprocal of the retention time of dietary organic matter in the reticulo-rumen for the leaf and stem fractions. The difference between the regression for leaf and stem was not significant $(P>0.05)$. 


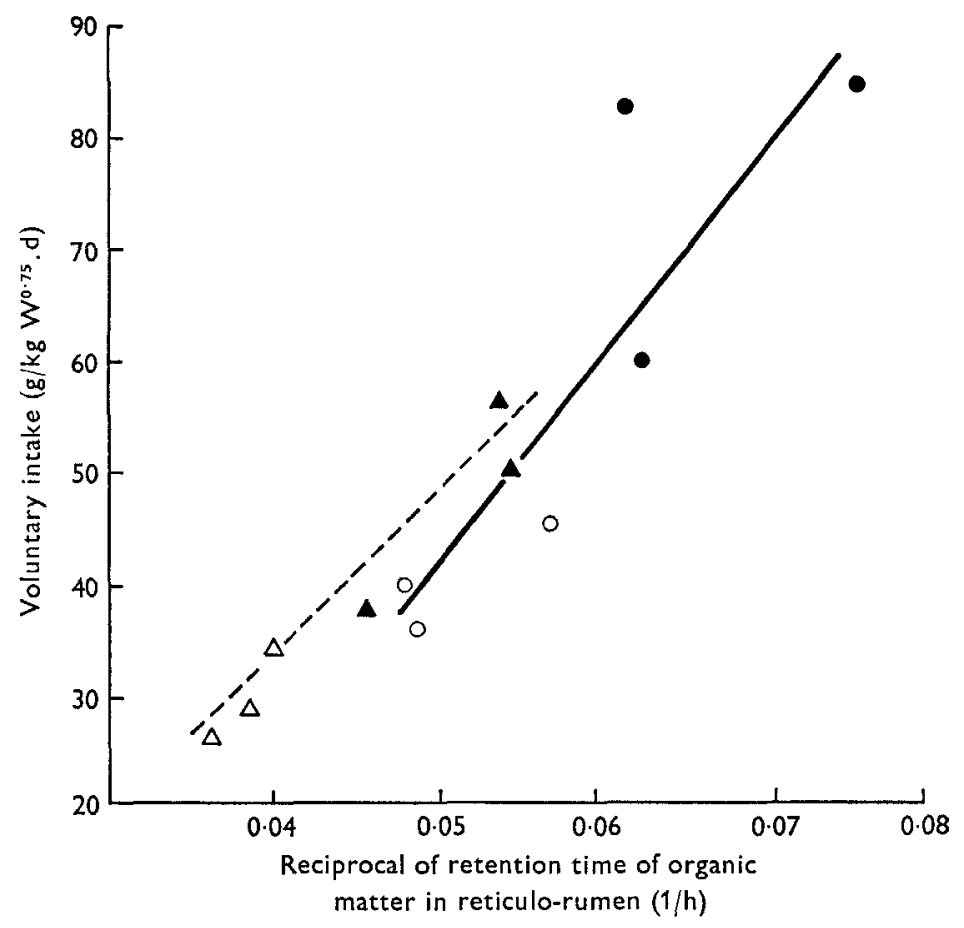

Fig. I. Relationship between voluntary intake by sheep given chopped and pelleted leaf and stem fractions from three grasses and retention time of dietary organic matter in the reticulorumen: - , leaf; ---- , stem; $O$, chopped leaf; $\bullet$, pelleted leaf; $\triangle$, chopped stem; $\Lambda$, pelleted stem. $W^{0 \cdot 75}$, metabolic body size (body-weight ${ }^{0.75}$ ); leaf fraction contained: leaf lamina, seed head and leaf sheath that had separated from stem, and lighter fractions of stem; stem fraction contained: leaf sheath, true stem and some leaf lamina. For details of preparation of fractions, see p. I60.

\section{DISCUSSION}

The higher intake of chopped leaf than stem occurred although DM digestibilities of the two fractions were similar and this is in agreement with previous work on separated leaf and stem fractions (Laredo \& Minson, 1973) but in disagreement with earlier conclusions of Milford \& Minson (1966, 1968) who found that the intake was not related to the proportion of leaf in the diet. In the previous work unseparated chopped grass was fed and no attempt was made to account for differences in digestibility between the leaf and stem fractions. The main reason for the higher voluntary intake of leaf in the present experiments appeared to be the shorter time that this fraction was retained in the reticulo-rumen (Fig. $\mathrm{I}$ ). This is supported by the observation that grinding and pelleting increased voluntary intake of both leaf and stem and at the same time retention time was reduced (Fig. I). Although pelleting increased intake of both fractions it did not reduce the difference in intake between leaf and stem fractions. This was probably due to the higher modulus of fineness and associated smaller surface area of the ground stem fractions (Table I). The reduction in retention time found when the grass was ground and pelleted may have been due to an increase in the rate of digestion but could also be caused by ground particles being sufficiently small to pass through the reticulo-omasal orifice. If this occurred then partially 
digested particles would leave the rumen and result in the observed depression in the digestion of DM (Table 2), NDF and ADF (Table 3). Although the fistulated sheep ate $30 \%$ more pelleted than chopped grass (Laredo, 1975) it appears unlikely that this difference in intake could account for more than $20 \%$ of the shorter retention time of the pelleted food since level of feeding has only a small effect on the retention time of organic matter in the reticulo-rumen (Minson, 1966).

Some rumen bacteria are attached to the surface of food particles in the rumen (Monson, Powell \& Burton, 1972) and hence the greater the surface area exposed to bacteria the more rapidly the food is digested. In vitro studies have shown that finely ground food is digested more rapidly than coarsely ground food (Minson \& Milford, 1967). Thus the chaffed leaf fraction, which had a surface area three times that of the stem fraction (Table I), might be expected to be more rapidly digested than the stem fraction, and this may account for some of the shorter retention time observed with the leaf fraction. This conclusion is supported by the results with grinding and pelleting which would have increased the surface area available for bacterial attachment as soon as the pellets disintegrated in the rumen. Observations showed that pellets were broken down in less than $\mathrm{I}$ min.

Finding a difference in voluntary intake between pelleted leaf and stem fractions was unexpected, since all ground diets had a modulus of fineness of less than $2 \cdot 5$ and Wilkins, Lonsdale, Tetlow \& Forrest (1972) found no difference in voluntary intake of ryegrass diets with a modulus of fineness of $0.98,1 \cdot 60$ and $2 \cdot 50$. However, with lowdigestibility forage, particle size appears to be an important factor controlling the voluntary intake of pellets. Recently, Laredo (1975) measured the voluntary intake by sheep of pellets made from $S$. splendida stem ground through $3 \mathrm{~mm}$ and $\mathrm{I} \mathrm{mm}$ screens (modulus of fineness $2 \cdot 0$ and 0.9 ). Voluntary intake of the finely ground stem was $25 \%(P<0.05)$ higher than that of the coarsely ground stem indicating that physical factors limiting voluntary intake had not been completely eliminated by the use of a $3 \mathrm{~mm}$ screen. In any future grinding and pelleting studies with mature diet it is desirable to use a grinder with much smaller holes than $3 \mathrm{~mm}$ if particle size and surface area are to be eliminated as factors limiting voluntary intake. Recently Greenhalgh \& Reid (1973) have suggested that larger particles can leave the reticulorumen of cattle than that of sheep. If this suggestion is correct then it is possible that the difference in voluntary intake between leaf and stem fractions recorded using sheep might be smaller with cattle.

The stem fractions had a mean bulk density three times greater than that of the leaf fractions and according to Baumgardt (1970) this higher density should have resulted in a higher voluntary intake of the stem whereas the opposite was observed here. When the difference in bulk density betweerı leaf and stem was removed by grinding and pelleting, the difference in voluntary intake between leaf and stem was even higher than was found with the chopped forages. Bulk density does not appear to be a primary factor controlling voluntary intake of roughages.

Thornton \& Minson (1972) showed that retention time of Panicum species was related to the proportion of NDF and lignin in the diet, so the higher voluntary intake of the leaf fraction might be caused by the lower fibre and lignin content. 
Although grinding and pelleting had little or no effect on the fibre and lignin content of the diet, it led to an increase in voluntary intake. This anomaly is caused by the use of a method of fibre and lignin analysis which measures chemical composition without taking into account the physical structure of the fibre. Thus grinding and pelleting alters the physical structure of the fibre and any effect this might have on voluntary intake, but will not alter the chemical composition of the fibre or the protective action of the lignin. Only by ball-milling can the digestibility of fibre be increased (Dehority \& Johnson, 1960; Tilley \& Terry, 1963). If grinding and pelleting without altering the fibre content can increase voluntary intake of roughages by sheep then any correlation between voluntary intake and chemically determined fibre content of the plant is not causal in origin but must rely on a relationship between chemically determined fibre and the physical structure of the plant.

The stem fractions were hard and coarse and appeared most unappetizing so the lower voluntary intake of the stem might have been caused by the low 'palatability' of the stem fraction. Greenhalgh \& Reid (197I) showed that with an unpalatable oat straw the quantity of DM in the reticulo-rumen was much less than when the animals were given the diet through a rumen fistula or a more palatable diet was fed. In this study, however, the mean quantity of DM in the rumen of sheep given the stem fraction was not significantly different from that found when the sheep were fed on leaf fractions, indicating that differences in palatability between leaf and stem fractions was not a major factor causing the difference in voluntary intake.

It was concluded that the differences in voluntary intake between leaf and stem were caused by physical factors and not by a nutrient deficiency.

The authors wish to thank Messrs J. Anderson, R. Maroske and G. Taylor for help with the preparation and feeding of the separated grass fractions. We also thank Messrs M. N. McLeod, A. Johnson and H. Kiers for help with the chemical analysis and Mr M. L. Graydon for assistance with computing.

\section{REFERENCES}

American Society of Agricultural Engineers (1967). Agricultural Engineers' Yearbook, I967 p. 301.

Association of Official Agricultural Chemists (1965). Official Methods of Analysis Ioth ed., p. I6. Washington, DC: Association of Official Agricultural Chemists.

Baumgardt, B. R. (1970). In Physiology of Digestion and Metabolism in the Ruminant p. 235 [A. T. Phillipson, editor]. Newcastle upon Tyne: Oriel Press.

Clancy, M. J. \& Wilson, R. C. (1966). Proc. 1oth int. Grassld Congr., Helsinki p. 445.

Dehority, B. A. \& Johnson, R. R. (1960). F. Anim. Sci. 19, 1257.

Greenhalgh, J. F. D. \& Reid, G. W. (1971). Br. F. Nutr. 26, 107.

Greenhalgh, J. F. D. \& Reid, G. W. (1973). Anim. Prod. 16, 223.

Harmond, J. E., Klein, I. M. \& Branderberg, N. R. (I96I). Agric. Handb. Forest Serv. U.S. no. I 79.

Johnson, A. D. \& Simons, J. G. (1972). Communs Soil Sci. Plant Analysis 3, I.

Laredo, M. A. (1975). The voluntary intake by sheep given separated leaf and stem fractions of tropical grasses. PhD Thesis, University of Queensland.

Laredo, M. A. \& Minson, D. J. (1973). Aust. F. agric. Res. 24, 875.

McLeod, M. N. \& Minson, D. J. (I971). F. Br. Grassld Soc. 26, 251.

Milford, R. \& Minson, D. J. (1966). Proc. 9th int. Grassld Congr., Sao Paulo, Brazil p. 8 I 5.

Milford, R. \& Minson, D. J. (1968). Aust. F. exp. Agric. Anim. Husb. 8, 4I 3.

Minson, D. J. ( 1966). Br. Ұ. Nutr. 20, 765 .

Minson, D. J. (1967). Br. F. Nutr. 21, 587. 
Minson, D. J. \& Cowper, J. L. (1966). Br. $\mathcal{F}$. Nutr. 20, 757.

Minson, D. J. \& Milford, R. (1967). F. Br. Grassld Soc. 22, I70.

Minson, D. J. \& Milford, R. (1969). F. agric. Sci., Camb. 7I, 38 I.

Monson, W. G., Powell, J. B. \& Burton, G. W. (I972). Agron. F. 64, 231.

Tetlow, R. M. \& Wilkins, R. J. (1972). Anim. Prod. 14, 335.

Thornton, R. F. \& Minson, D. J. (1972). Aust. F. agric. Res. 23, 87 r.

Tilley, J. M. A. \& Terry, R. A. (1963). F. Br. Grassld Soc. 18, 104.

Van Soest, P. J. (1963). F. Ass. off. agric. Chem. 46, 825 .

Weston, R. H. (1959). Aust. F. agric. Res. ro, 865.

Wilkins, R. J., Lonsdale, C. R., Tetlow, R. M. \& Forrest, T. J. (1972). Anim. Prod. r4, 177. 